\title{
Stability of amlodipine besylate and atenolol in multi-component tablets of mono-layer and bi-layer types
}

\author{
SAJJAN ARYAL ${ }^{1,2}$ \\ NATAŠA ŠKALKO-BASNET ${ }^{1, *}$ \\ 1 The School of Pharmaceutical \\ and Biomedical Sciences, Faculty of \\ Science and Technology, Pokhara \\ University, PO Box 427, Pokhara \\ Nepal \\ 2 Quest Pharmaceuticals (P) Ltd. \\ Chhata Pipara, Bara, Nepal
}

\begin{abstract}
Multi-drug tablets of amlodipine besylate and atenolol were prepared as either mono-layer (mixed matrix) or bi-layer tablets containing each drug in a separate layer by using similar excipients and processing. Each tablet batch was packed in strip and blister packs and kept under accelerated temperature and humidity conditions. The stability of two tablet and packaging types was compared by HPLC analysis after $0,1,3$ and 4.5 months and expressed as the content of intact amlodipine and atenolol. The content of atenolol did not decline regardless of tablet and packaging type. Amlodipine content in bi-layer tablets decreased to about 95 and $88 \%$ when packed in strips and blisters, respectively. When prepared as mono-layer tablets, the content decreased to 72 and $32 \%$, respectively. The study revealed that the bi-layer tablet formulation was more stable than the mono-layer type. Further, the stability was increased when the tablets were packed in aluminium strips as compared to PVC blisters.
\end{abstract}

Keywords: amlodipine, atenolol, mono-layer, bi-layer tablet, stability

Fixed-dose drug combination decreases the risk of patient non-compliance and should be considered in patients with chronic conditions like hypertension (1). Clinically, combination therapy in hypertension treatment involving two or more drugs from different classes can result in better drug efficacy and is recommended for the initial stage of hypertension treatment (2). The combination of atenolol and amlodipine significantly decreases blood pressure and systolic blood pressure variability. In spontaneously hypertensive rats, the synergistic effect between atenolol and amlodipine results in lowering and stabilizing of blood pressure (3). Both beta blockers and dihydropyridine calcium antagonist are widely used in the treatment of hypertension. Their combination is a logical choice and can also neutralize the side effects of each drug. Combination therapy is likely to be the optimal way to control blood pressure and reduce blood pressure

\footnotetext{
* Correspondence, e-mail: natasa.skalko-basnet@farmasi.uit.no; Section of Pharmaceutics and Biopharmaceutics, Department of Pharmacy, University of Tromsø, Universitetsveien 57, N-9037 Tromsø, Norway
} 
S. Aryal and N. Škalko-Basnet: Stability of amlodipine besylate and atenolol in multi-component tablets of mono-layer and bi-layer types, Acta Pharm. 58 (2008) 299-308.

variability in the treatment of hypertension as well as in prevention of stroke in hypertension (4). The stability of the product, on the other hand, remains a pharmaceutical challenge in multi-drug formulations.

Amlodipine besylate, like all members of 1,4-dihydropyridine calcium channel blockers, is photosensitive and liable to degradation both in solution and in solid state. Light catalyses its oxidation to pyridine derivatives, such as amlox (2-[(2-aminoethoxy)met hyl]-4-(2-chlorophenyl)-3-ethoxycarbonyl-5-methoxycarbonyl-6-methyl pyridine), which lack therapeutic effects (5). Forced degradation studies show amlodipine to be degrading slowly under thermal stress (more in solution than in solid state), degrading faster under photo-stress (more rapidly under UV $366 \mathrm{~nm}$ than under $254 \mathrm{~nm}$ and less in natural light) and even more under acidic, alkaline and oxidative stress - the highest being in alkaline conditions $(6,7)$. Another pharmaceutical problem is the reported incompatibility in the solid formulation between amlodipine besylate and lactose in the presence of basic excipients (magnesium stearate) and water (8). Atenolol is reported to be photoreactive when exposed to UVA-UVB radiation with photodegradation increasing with a decrease in the $\mathrm{pH}$ value. The main photodegradation product at $\mathrm{pH} 7.4$ was identified as 2-(4-hydroxyphenyl) acetamide (9).

This research work was designed to compare the stability of two types of tablets - a mono-layer tablet containing amlodipine besylate and atenolol in the same matrix and a bi-layer tablet containing amlodipine besylate and atenolol in separate layers. Similar excipients, processing and storage conditions were applied for both tablet types and two different packaging materials (aluminium and PVC) were used to study the influence of packaging material. The results were obtained from HPLC analyses of drug content in the tablets stored under accelerated temperature and humidity conditions.

\section{EXPERIMENTAL}

\section{Materials}

All the materials were generously provided by Quest Pharmaceuticals (P) Ltd, Nepal. All raw materials used to manufacture the tablets were of pharmaceutical grade and included amlodipine besylate BP (Cadila Pharma, India), atenolol IP (IPCA Laboratories, India), maize starch IP (Universal Starch, India), microcrystalline cellulose (powder) IP (Chemsfield, India), calcium hydrogen phosphate dihydrate IP (Enar Chemie, India), sodium starch glycolate IP (Universal Starch, India), magnesium stearate IP (Paras Fine Organics, India), colloidal silicon dioxide IP (Degussa, Belgium) and erythrosine lake colour ISI (Roha Dye Chem, India).

Chemicals and solvents for analysis: methanol, acetonitrile and water for HPLC (LiChrosolv brand) were purchased from Merck Ltd, India. Triethylamine was a product of Qualigens Fine Chemicals, India. Sodium octane sulphonate (1-octane sulphonic acid sodium salt) for chromatography was purchased from Spectrochem, India, and o-phosphoric acid, from Central Drug House, India. All the chemicals used were of analytical grade.

Working standards of amlodipine besylate and atenolol were also kind gifts from Quest Pharmaceuticals (P). 
S. Aryal and N. Škalko-Basnet: Stability of amlodipine besylate and atenolol in multi-component tablets of mono-layer and bi-layer types, Acta Pharm. 58 (2008) 299-308.

\section{Manufacturing and packaging of tablets}

Both types of tablets were manufactured in batches of ten thousand tablets each as per formulae given in Table I. Three granulations were prepared separately - two single ingredient granules of amlodipine and atenolol and one of mixed granules containing both. All the granules were prepared by the wet granulation method using starch paste as a binder. The active ingredients and colour (in amlodipine granules) were mixed with the diluents using the geometrical dilution method manually and granulated by mixing

Table I. Mono-layer $(A)$ and bi-layer tablet formulations (B)

\begin{tabular}{lc}
\hline \multicolumn{1}{c}{ A } & mg per tablet \\
\hline Amlodipine besylate & 6.90 \\
Atenolol & 50.00 \\
Maize starch & 90.10 \\
Microcrystalline cellulose (powder) & 95.00 \\
Calcium hydrogen phosphate dihydrate & 90.00 \\
Sodium starch glycolate & 15.00 \\
Magnesium stearate & 1.00 \\
Colloidal silicon dioxide & 2.00 \\
Total mass of mono-layer tablet & 350.00 \\
\hline \multicolumn{1}{c}{ B. Amlodipine layer } & \\
Amlodipine besylate & 6.90 \\
Maize starch & 50.10 \\
Microcrystalline cellulose (powder) & 50.00 \\
Calcium hydrogen phosphate dihydrate & 40.00 \\
Sodium starch glycolate & 15.00 \\
Magnesium stearate & 1.00 \\
Colloidal silicon dioxide & 2.00 \\
Erythrosine Lake colour & 0.15 \\
Total mass & 165.00 \\
\hline
\end{tabular}

B. Atenolol layer

Atenolol 50.00

Maize starch $\quad 50.00$

Microcrystalline cellulose (powder) $\quad 40.00$

Calcium hydrogen phosphate dihydrate $\quad 32.00$

Sodium starch glycolate $\quad 10.00$

Magnesium stearate $\quad 1.00$

Colloidal silicon dioxide $\quad 2.00$

Total mass $\quad 185.00$

Total mass of bi-layered tablet $\quad 350.00$ 
S. Aryal and N. Škalko-Basnet: Stability of amlodipine besylate and atenolol in multi-component tablets of mono-layer and bi-layer types, Acta Pharm. 58 (2008) 299-308.

with starch paste in a paddle type Mass Mixer (10 liter capacity, Grovers Equipments, India). The wet mass were shredded from a 16 mesh sieve and dried in a fluidized bed dryer (30 kg capacity, Kothari Pharma, India) at $50{ }^{\circ} \mathrm{C}$ until the moisture content (determined by a moisture balance, IR-30 Denver Instruments, USA) came to about $4.5 \%$. Finally, the granules were sieved again from a 16 mesh sieve $(1.19 \mathrm{~mm})$, mixed with sodium starch glycolate and lubricated with magnesium stearate and colloidal silicon dioxide as per their respective formulae.

The lubricated granules were compressed into mono-layer and bi-layer tablets using a 27-station double-sided Rotary Tablet Press (Cadmach, India). A set of round biconvex 10-mm diameter punches was used for both tablet types. Mono-layer tablets were compressed at a theoretical average mass of $350 \mathrm{mg}$. Bi-layer parts were used to compress amlodipine (pink) and atenolol (white) as separate layers in the bi-layer tablet. The mass of amlodipine layer was adjusted to $165 \mathrm{mg}$ and atenolol layer to $185 \mathrm{mg}$, making the final tablet mass $350 \mathrm{mg}$. Vacuum was employed in the suction port of the machine to avoid mixing of the two granules.

Both types of tablets were then packed in strips and blisters of 10 tablets each. Strips were prepared from $0.03 \mathrm{~mm}$ polylaminated aluminium foils (Hindalco, India) using a strip packing machine (Kulbindra Engineering, India). Blisters were packed in $0.025 \mathrm{~mm}$ heat sealing laquer (HSL)-coated aluminium foil (Hindalco, India) and $0.25 \mathrm{~mm}$ clear transparent PVC (Fenoplast India) using a blister machine (Elmach Packaging, India).

\section{Assay of amlodipine and atenolol}

Instrumentation. - Isocratic HPLC System (Knauer, Germany) was used for the analysis. The solvent delivery system consisted of a Smartline HPLC pump model 1000 with a 10-mL pump head. The detector was a spectrophotometer type Smartline UV 2500. PC-based software Eurochrom 2000 for Windows, V.3.05, was employed for data acquisition, processing and instrument control. A $20-\mu \mathrm{L}$ loop was used for sample injection. Reversed phase octadecyl silane (ODS) C-18 column stainless steel, $250 \mathrm{~mm}$ x $4.6 \mathrm{~mm}$ internal diameter, with $10 \mu \mathrm{m}$ particle size (Eurosper 100-10, Knaur) was used as the analytical column. The analysis was carried out at a $1.5 \mathrm{~mL} \mathrm{~min}^{-1}$ flow rate and detection at $238 \mathrm{~nm}$. Analytical columns were used at ambient laboratory temperature that was kept within $22-27^{\circ} \mathrm{C}$ with a room air conditioner.

Mobile phase preparation. - Mobile phase consisted of HPLC grade water/methanol/ acetonitrile (34:33:33) containing triethylamine $(0.034 \%)$ and sodium octane sulphonate $(0.1 \%)$. The $\mathrm{pH}$ of the solution was adjusted to 2.8 with $50 \% o$-phosphoric acid. The solution was sonicated for $5 \mathrm{~min}$ with a laboratory sonicator $(61$ model, Medica Instruments, India) and filtered from Axiva brand disc filters $(0.45 \mu \mathrm{m}$; Axiva Sichem (P) Ltd, India) using a vacuum filtration kit.

Standard preparation. - Amlodipine besylate accurately weighed to $69.00 \mathrm{mg}$ (equivalent to $50.00 \mathrm{mg}$ amlodipine) was transferred to a $50-\mathrm{mL}$ volumetric flask and dissolved in about $25 \mathrm{~mL}$ of mobile phase by manual shaking and the volume was adjusted with the mobile phase. An liquot $(5 \mathrm{~mL})$ of the above solution was transferred to a $100-\mathrm{mL}$ volumetric flask. Atenolol (50.00 mg) was dissolved in about $50 \mathrm{~mL}$ of mobile phase by manual shaking and the final volume $(100.00 \mathrm{~mL})$ was adjusted with the mobile phase. 
S. Aryal and N. Škalko-Basnet: Stability of amlodipine besylate and atenolol in multi-component tablets of mono-layer and bi-layer types, Acta Pharm. 58 (2008) 299-308.

The solution was finally filtered using a syringe filtration kit from Ultipore (N66 brand $0.2 \mu \mathrm{m}$ membrane filter, $13 \mathrm{~mm}$ diameter; PALL Life Sciences, India).

Sample preparation. - Sample tablets were removed from their strip/blister and the average mass of 20 tablets was determined. The tablets were crushed using a mortar and pestle to fine powder. A quantity of powder equivalent to the average mass of the tablets was accurately weighed and transferred to a $100-\mathrm{mL}$ volumetric flask. The flask was half-filled with the mobile phase and shaken manually for 10 minutes. The volume was made up to $100 \mathrm{~mL}$ with the mobile phase and kept in the sonicator for 10 minutes. An aliquot of the solution was centrifuged for $5 \mathrm{~min}$ at $2500 \mathrm{rpm}$; about $2 \mathrm{~mL}$ of the solution was then filtered through a $0.2 \mu \mathrm{m}$ Ultipore N66 membrane filter and kept in the sample vial with an air tight lid.

Stability study. - The samples were kept in the stability chamber (Thermaolab, India) set at accelerated storage conditions (10) of $40 \pm 2{ }^{\circ} \mathrm{C}$ and $75 \pm 5 \%$ relative humidity. Contents of both amlodipine and atenolol in the samples were periodically monitored by the HPLC analysis. Analyses were carried out at time 0 and after storage of 1, 2, 3, and 4.5 months in the stability chamber. The comparison was statistically evaluated by Student's $t$ test.

\section{RESULTS AND DISCUSSION}

Amlodipine and atenolol combined in the same drug dosage form are gaining popularity among pharmaceutical manufacturers. However, data on the stability of such products are not disclosed and remain mostly with the manufacturer. As the combination of amlodipine and atenolol is not official in the therapeutic Compendia, quantitative analyses of amlodipine $(6,11,12)$ and atenolol $(13,14)$ in pharmaceutical dosage forms are generally described by UV spectrophotometric and high performance liquid chromatographic techniques. Determination of both components in multi-drug tablets is done by various methods such as UV spectrophotometry, $\operatorname{HPLC}$, and $\operatorname{HPTLC}(15,16)$.

Resolution of multicomponent preparations is often a complex analytical problem since combined substances may have different chemical structures but similar properties, e.g., chromatographic behaviour (13). Therefore, the development and validation of the modified analytical method for the concomitant assay of amlodipine and atenolol consumed considerable time of the research. The methods described in the literature for the determination of amlodipine and atenolol $(11,12,15,16)$ were, in our conditions, found to be unsuitable regarding the resolution of components, large tailing factors and inconsistency. We based our method on the conditions described by Klinkenberg et al. (11) but we had to adjust the mobile phase composition. The analytical variables were optimized to obtain the desired chromatographic characteristics, including resolution of the components, peak symmetry (tailing factors at least less than 2) and theoretical plate numbers over 1000 (10).

\section{Validation of the HPLC method}

As we adjusted the assay conditions, validation of the modified method was necessary. The method was validated through injection repeatability, linearity tests, recovery 
S. Aryal and N. Škalko-Basnet: Stability of amlodipine besylate and atenolol in multi-component tablets of mono-layer and bi-layer types, Acta Pharm. 58 (2008) 299-308.

test, $L O D, L O Q$, and accuracy (11). In the injection repeatability test, the relative standard deviations (RSD) of the peak area of six consecutive injections were found to be 0.8 and $0.7 \%$ for atenolol and amlodipine, respectively. Linearity test for the response was conducted by using five standard solutions containing $40,45,50,55$, and $60 \mu \mathrm{g} \mathrm{mL}-1$ of amlodipine base and 400, 450,500, 550, and $600 \mu \mathrm{g} \mathrm{mL}^{-1}$ of atenolol, respectively. Regression analysis showed satisfactory results with the squared value of the Pearson product moment correlation coefficient of 0.9966 for amlodipine and 0.9989 for atenolol. The recovery test (in triplicate, the standard addition method) was carried out using simulated tablet samples (samples of a known quantity of the drug along with placebo mixtures of excipients in the same composition as in the actual mono-layer tablets) of 90, 100 and $110 \%$ strength. The test resulted in mean recovery of $99.8 \% \pm$ for amlodipine and $99.5 \% \pm$ for atenolol and showed acceptable accuracy. The mean recovery was in good agreement with the published data for amlodipine (12) and atenolol $(13,14)$. Limit of detection (LOD) was found to be 3.63 and $5.31 \mu \mathrm{g} \mathrm{mL}^{-1}$ for amlodipine and atenolol, respectively. Limit of quantification (LOQ) was 11.01 and $16.09 \mu \mathrm{g} \mathrm{mL}^{-1}$ for amlodipine and atenolol, respectively. The values for $L O D$ and $L O Q$ were rather high compared to the values of Klinkenberg et al. (11), who were determining the residues of amlodipine alone, whereas, we were dealing with a mixed drug system.

Specificity tests were carried out by comparing the chromatographic peaks of the mobile phase only, excipients (placebo mixture) added to the mobile phase and treated like the sample and the standard containing amlodipine and atenolol. Placebo mixture was prepared by mixing the same excipients in the same composition as in the actual mono-layer tablets. Placebo was added to standard solutions in the same proportion that would be contained in the dilution of the actual formulation. The chromatogram with only placebo showed no significant peaks in the positions where the principal peaks would appear (Fig. 1). The chromatographic results of the standard with and without addition of the excipients were compared and no changes were observed after addition of excipients. It is known that atenolol can be determined in the presence of its major degradation product (14) and therefore the measurements were focused on drugs content alone.

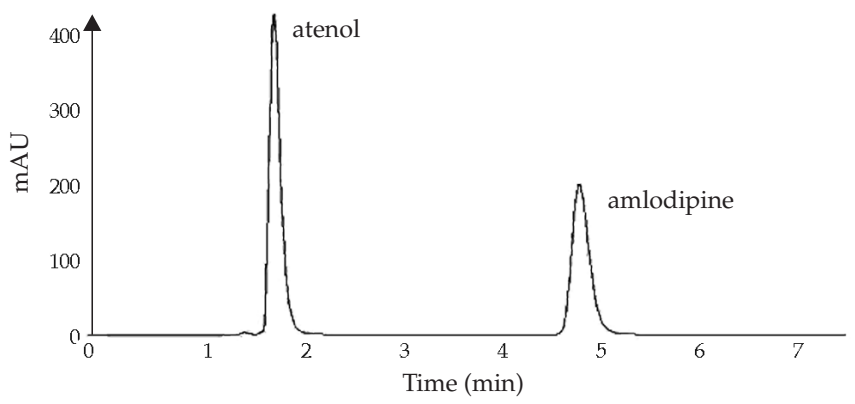

Fig. 1. A representative chromatogram and the chromatographic parameters of a standard solution containing amlodipine $\left(t_{\mathrm{R}}=4.95 \pm 0.11 \mathrm{~min}\right)$ and atenolol $\left(t_{\mathrm{R}}=1.85 \pm 0.01 \mathrm{~min}\right)$. HPLC conditions: column: $\mathrm{RP}_{18}$ (ODS, 4.6 x $250 \mathrm{~mm}$ ); eluent: water/methanol/acetonitrile (34:33:33) with triethylamine $(0.034 \%)$ and sodium octane sulphonate $(0.1 \%), \mathrm{pH} 2.8$; flow rate: $1.5 \mathrm{~mL} \mathrm{~min}^{-1}$; detection: UV $238 \mathrm{~nm}$. 
S. Aryal and N. Škalko-Basnet: Stability of amlodipine besylate and atenolol in multi-component tablets of mono-layer and bi-layer types, Acta Pharm. 58 (2008) 299-308.

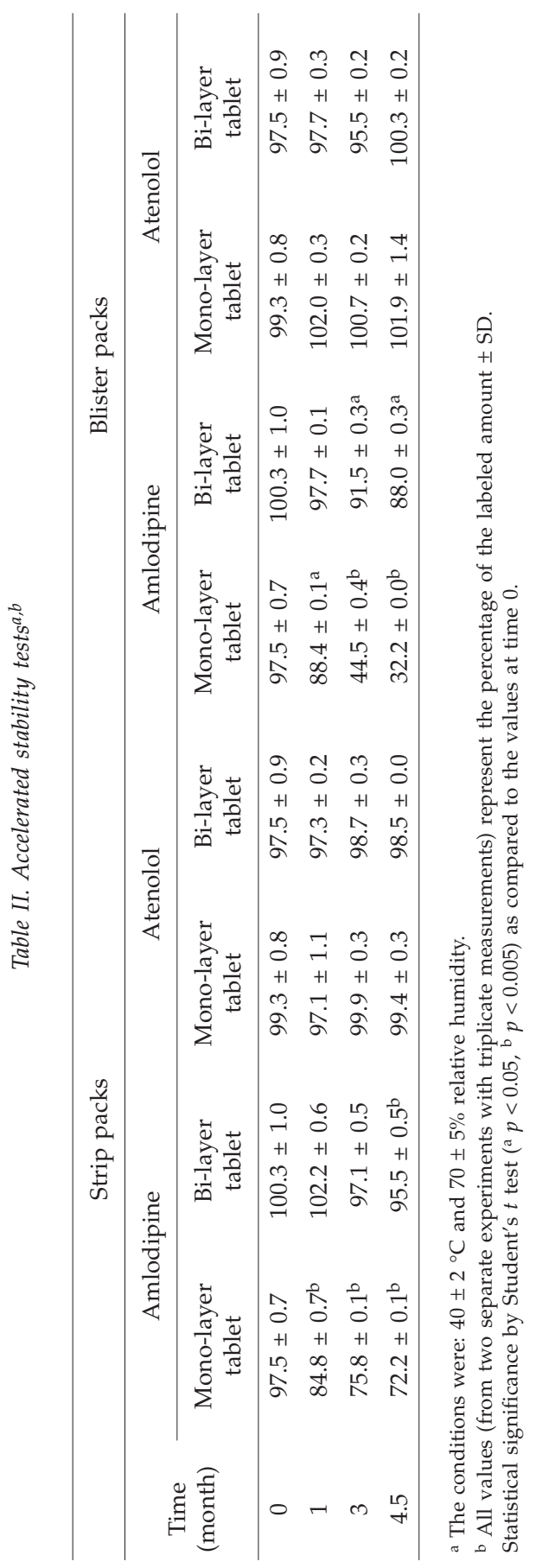


S. Aryal and N. Škalko-Basnet: Stability of amlodipine besylate and atenolol in multi-component tablets of mono-layer and bi-layer types, Acta Pharm. 58 (2008) 299-308.

\section{Stability tests}

The stability test results in terms of the average content of amlodipine and atenolol per tablet, in percentage with respect to the labeled amount, are presented in Table II. The quantity of atenolol remained fairly constant in both strip and blister packing until the end of the stability study period (4.5 months). No significant degradation was observed in either the mono-layer or bi-layer tablets (Table II).

Amlodipine content in the strip packaging decreased, in the mono-layer tablets, to $72.2 \%(p<0.005)$. When prepared as bi-layer tablets and packed in strips, a significant decrease $(p<0.005)$ was observed only after 4.5 months of storage. To be sure that the values were the result of degradation and not of variability in tablet mass, we determined the tablet mass variation for the mono-layer type $(+2.2$ and $-1.7 \%)$ and the bi-layer type (+2.3 and $-3.1 \%)$. Moreover, we also determined the individual mass variations in separate layers and found them to be +4.3 and $-3.7 \%$ for the atenolol layer and +3.8 and $-6.2 \%$ for the amlodipine layer. Taking into account individual mass variations, the decrease in the amlodipine content in bi-layer tablets packed in strips does not represent a significant degradation. Amlodipine content sharply decreased in the blister packed tablets - both in the mono-layer $(p<0.005)$ and bi-layer formulations. The decrease was more dramatic in the mono-layer type dropping to about $32.3 \%$ within 4.5 months (Table II). This significant decline in content $(p<0.005)$ is clearly the result of amlodipine degradation since it is more than what could be contributed to mass variation.

The stability results suggest that atenolol was fairly stable in both formulations in strip packing (Table II). The variations in atenolol content (from 97.1 to $102.0 \%$ ) correspond to the tablet mass variation +4.3 to $-3.7 \%$. The contribution from tablet mass variation can be expected to be a little higher in bi-layer tablets than in mono-layer tablets. On the other hand, the content of amlodipine in mono-layer strips, mono-layer and bi-layer blisters was gradually decreasing with a significant change (more than $5 \%$ ) as per ICH (10). The results (Table II) indicate that, in regard to amlodipine content, strip packaging is preferable to blister packaging $(p<0.005)$. Moreover, the bi-layer type is significantly $(p<0.005)$ more suitable than the mono-layer type for all combined type formulations. Although the manufacturing of bi-layer tablets requires more time, skill and financial resources, it appears to be a preferable choice for combined drugs formulations.

As no literature data are available on the stability of the combination dosage forms of these two drugs, we expect that more research will be done into the stability problems of such combined formulations.

\section{CONCLUSIONS}

Amlodipine degraded more rapidly than atenolol in both types of tablets and packing materials. The drugs in bi-layered tablets were found to be more stable than in mono-layer tablets, and strip packaging was found to be superior to blister packaging considering the stability parameter. We recommend the bi-layered type tablets packed in aluminium strips as a preferable choice for formulation of amlodipine and atenolol as single dosage form tablets. It would be interesting to confirm the degradation products of both drugs, and to quantify them. 
S. Aryal and N. Škalko-Basnet: Stability of amlodipine besylate and atenolol in multi-component tablets of mono-layer and bi-layer types, Acta Pharm. 58 (2008) 299-308.

Acknowledgements. - The authors are grateful to Quest Pharmaceuticals (P) Ltd., Nepal, for providing materials and equipment for the research and to Mr. Kamlesh Dutta for his help with the HPLC analysis.

\section{REFERENCES}

1. S. Bangalore, G. Kamalakkannan, S. Parkar and F. H. Messerli, Fixed-dose combinations improve medication compliance: a meta-analysis, Am. J. Med. 120 (2007) 713-719; DOI: 10.1016/ J.AMJMED. 2006.08.033.

2. A. V. Chobanian, G. L. Bakris, H. R. Black, W. C. Cushman, L. A. Green, J. L. Izzo Jr., D. W. Jones, B. J. Materson, S. Oparil, J. T. Wight Jr. and E. J. Rocella, Seventh report of the joint national committee on prevention, detection, evaluation, and treatment of high blood pressure, Hypertension 42 (2003) 1206-1252.

3. L. Xu, F-M. Shen, H. Shu, C-Y. Miao, Y-Y. Jiang and D-F. Su, Synergism of atenolol and amlodipine on lowering and stabilizing blood pressure in spontaneously hypertensive rats, Fund. Clin. Pharmacol. 18 (2004) 33-38.

4. G. Ling, A-J. Liu, F-M. Shen, G-J. Cai, J-G. Liu and D-F. Su, Effects of combination therapy with atenolol and amlodipine on blood pressure control and stroke prevention in stroke-prone spontaneously hypertensive rats, Acta Pharmacol. Sin. 28 (2007) 1755-1760; DOI: 10.1111/j.1745-7254. 2007.00630.x.

5. G. Ragno, A. Garofalo and C. Vetuschi, Photodegradation monitoring of amlodipine by derivative spectrophotometry, J. Pharm. Biomed. Anal. 27 (2002) 19-24; DOI: 10.1016/S0731-7085(01)00556-8.

6. K. R. Naidu, U. N. Kale and M. S. Shingare, Stability indicating RP-HPLC method for simultaneous determination of amlodipine and benezepril hydrochloride from their combination drug product, J. Pharm. Biomed. Anal. 39 (2005) 147-155; DOI: 10.1016/J.JPBA.2005.04.001.

7. B. G. Chaudhari, N. M. Patel and P. B. Shah, Stability indicating RP-HPLC method for simultaneous determination of atorvastatin and amlodipine from their combination drug products, Chem. Pharm. Bull. 55 (2007) 241-246.

8. A. Abdoh, M. M. Al-Omari, A. A. Badwan and A. M. Y. Jaber, Amlodipine besylate-excipients interaction in solid dosage form, Pharm. Dev. Technol. 9 (2004) 15-24; DOI: 10.1081/PDT-120027414.

9. V. Andrisano, R. Gotti, A. Leoni and V. Cavrini, Photodegradation studies on atenolol by liquid chromatography, J. Pharm. Biomed. Anal. 21 (1999) 851-857.

10. International Conference on Harmonization of Technical Requirements for Registration of Pharmaceuticals for Human Use, Stability testing of new drug substances and products, Q1A(R2), Current step 4 version dated 6 February 2003; http://www.ich.org.

11. R. Klinkenberg, B. Streel and A. Ceccato, Development and validation of a liquid chromatographic method for the determination of amlodipine residues on manufacturing equipment surfaces, J. Pharm. Biomed. Anal. 32 (2003) 345-352; DOI: 10.1016/S0731-7085(03)00109-2.

12. K. Kamat and S. C. Chaturvedi, Stability indicating assay method for amlodipine tablets, Ind. J. Pharm. Sci. 67 (2005) 236-239.

13. M. C. F. Ferraro, P. M. Castellano and T. S. Kaufman, Chemometric determination of amiloride hydrochloride, atenolol, hydrochlorothiazide and timolol maleate in synthetic mixtures and pharmaceutical formulations, J. Pharm. Biomed. Anal. 34 (2004) 305-314; DOI: 10.1016/S0731-7085(03)00521-1.

14. R. Ceresole, M. A. Moyano, M. T. Pizzorno and A. I. Segall, Validated reversed-phase HPLC method for the determination of atenolol in the presence of its major degradation product, J. Liq. Chromatogr. Rel. Tech. 29 (2006) 3009-3019; DOI: 10.1080/10826070600983393. 
S. Aryal and N. Škalko-Basnet: Stability of amlodipine besylate and atenolol in multi-component tablets of mono-layer and bi-layer types, Acta Pharm. 58 (2008) 299-308.

15. R. K. Barman, M. A. Islam, M. Ahmed, M. I. Ibne Wahed, R. Islam, A. Khan, M. B. Hossain and B. M. Rahman, Simultaneous high-performance liquid chromatographic determination of atenolol and amlodipine in pharmaceutical-dosage form, Pak. J. Pharm. Sci. 20 (2007) 274-279.

16. A. P. Argekar and S. G. Powar, Simultaneous determination of atenolol and amlodipine in tablets by high performance thin-layer chromatography, J. Pharm. Biomed. Anal. 21 (2000) 1137-1142.

$S A \check{Z} E T A K$

\section{Stabilnost amlodipin besilata $i$ atenola $u$ jednoslojnim $i$ dvoslojnim tabletama \\ SAJJAN ARYAL i NATAŠA ŠKALKO-BASNET}

Tablete s amlodipinom i atenololom pripremljene su ili u obliku jednoslojne tablete (miješani matriks) ili kao dvoslojne tablete (lijekovi u zasebnim slojevima) koristeći slične pomoćne tvari i uvjete tabletiranja. Tablete su pakirane u dvije vrste pakiranja, aluminijske folije (strip) ili PVC (blister) i čuvane u uvjetima ubrzanog starenja. Stabilnost je određivana pomoću HPLC metode nakon 0, 1, 2, 3 i 4,5 mjeseci i izražena kao sadržaj intaktnog lijeka.

Sadržaj atenolola nije se značajno promijenio bez obzira na tip tablete ili pakiranje. Sadržaj amlodipina u dvoslojnim tabletama smanjio se na 95\% (tablete u strip pakiranju) i $88 \%$ (tablete $\mathrm{u}$ blister pakiranju). Istodobno, $\mathrm{u}$ jednoslojnom tipu kombiniranih tableta sadržaj se smanjio na 72\% (strip pakiranje) i 32\% (blister pakiranje).

Rezultati pokazuju da su dvoslojne tablete s amlodipinom i atenololom stabilnije od jednoslojnih. Śtoviše, pakiranje tableta u aluminijsku foliju u obliku strip pakiranja povećava njihovu stabilnost u usporedbi s PVC pakirnim materijalom (blister).

Ključne riječi: amlodipin, atenolol, jednoslojna, dvoslojna tableta, stabilnost

The School of Pharmaceutical and Biomedical Sciences, Faculty of Science and Technology, Pokhara University, PO Box 427, Pokhara, Nepal 